\title{
STRUKTUR DAN FUNGSI EUFEMISME DALAM RUBRIK OBITUARI HARIAN KOMPAS
}

\author{
Yunus Sulistyono \\ Universitas Muhammadiyah Surakarta \\ ys122@ums.ac.id
}

\begin{abstract}
This research focuses on the use of euphemism in Obituary section of Kompas daily. The object of this research is the vocabulary that shows the use of stylistic peculiarities of euphemism in obituary. The data in this study includes 43 vocabulary of Kompas daily obituaries published September 2015 to April 2016. This is a descriptive qualitative study that is focusing on the structure and function of euphemisms. The obtained data were then classified based on the contexts. The data analysis was done based on unified referential methods. Based on the forms, the use of stylistic euphemisms include the level of words and phrases. The results of this study indicate that the euphemisms used in obituaries have some backgrounds which cover modesty, prestige and the act of exalting the merits given by the person reported in the news.
\end{abstract}

Keywords: Obituary, euphemism, form structure, functions

\section{Pendahuluan}

Gaya bahasa tidak dapat dipisahkan dari kehidupan sehari-hari. Bagi sebagian orang, gaya bahasa adalah alat untuk mengungkapkan kata-kata yang puitis-imaginatif dan retorikal (Lakoff 2003). Pemakaian gaya bahasa dalam kehidupan seharihari dapat ditemukan di surat kabar media cetak, salah satunya adalah harian Kompas. Wacana yang terdapat di dalam media Kompas antara lain wacana politik dan hukum, wacana opini, wacana berita internasional, wacana pendidikan dan kebudayaan, wacana Iptek, wacana lingkungan dan kesehatan, wacana ekonomi, dan wacana olah raga. Setiap wacana memiliki kekhasan di dalam penulisannya. Salah satu rubric yang terdapat dalam harian Kompas adalah Obituari. Rubrik ini memuat berita kematian tokoh-tokoh, baik nasional maupun internasional. Penggunaan bahasa dalam rubrik ini menarik untuk dikaji lebih dalam karena memiliki kekhasan. Salah satu gaya bahasa yang digunakan yakni gaya bahasa eufemisme.
Sebagai gaya bahasa, eufemisme adalah semacam acuan berupa ungkapan-ungkapan yang tidak menyinggung perasaan orang atau angkapan-ungkapan yang halus untuk menggantikan acuan-acuan yang dirasakan menghina, menyinggung perasaan atau menyugestikan sesuatu yang tidak menyenangkan (Keraf 2004, 132). Hal itu sejalan dengan pendapat Tarigan $(1985,128)$ yang mengungkapkan eufemisme adalah ungkapan yang lebih halus sebagai pengganti ungkapan yang dirasakan kasar dan dianggap merugikan dan yang tidak menyenangkan. Pendapat lain dikemukakan oleh Agni (2009, 110) yang menyatakan bahwa eufemisme adalah pengungkapan kata-kata yang dipandang tabu atau dirasa kasar dengan kata-kata lain yang lebih pantas atau dianggap halus. Dengan kata lain, eufemisme adalah ungkapan yang lebih halus digunakan untuk menggantikan ungkapan yang kasar dan merugikan.

Eufemisme dapat ditemukan dalam komunikasi sehari-hari. Sebagai salah satu media massa nasional, harian Kompas memiliki rubrik yang 
khusus untuk berita kematian tokohtokoh terkenal yaitu Obituari. Obituari pada surat kabar harian Kompas memiliki beberapa kekhasan. Wacana obituari menggunakan diksi yang khas dan dihipotesiskan memiliki pilihan gaya yang khas. Kekhasan ini menarik untuk diteliti. Gaya bahasa dapat digunakan untuk menemukan karakteristik sebuah wacana. Penggunaan gaya bahasa wacana obituari bermajas eufemisme contohnya adalah kata 'meninggal'.

(1) Advokat senior Indonesia itu meninggal pada Rabu (23/9) setelah dirawat selama lima hari di Rumah Sakit Pondok Indah. (Kompas, 25 September 2015, Adnan Buyung Nasution).

(2) Advokat senior Adnan Buyung Nasution, Rabu (23/9) pukul 10.15, meninggal di Rumah Sakit Pondok Indah, Jakarta Selatan. (Kompas, 25 September 2015, Adnan Buyung Nasution).

Kalimat di atas terdapat di dalam wacana obituari tentang berita meninggalnya Adnan Buyung Nasution. Kata 'meninggal' yang digunakan dalam kalimat (1) dan (2) dapat digolongkan ke dalam bentuk majas eufemisme. Majas ini sering digunakan di dalam wacana obituari harian Kompas. Fungsi pengunaan majas eufemisme pada kata 'meninggal' di atas digunakan untuk menggantikan kata-kata yang menyinggung perasaan atau sesuatu yang tidak menyenangkan keluarga yang ditinggalkan atau berduka.

Majas eufemisme digunakan untuk menggantikan kata-kata yang dirasa menyinggung perasaan atau menyugestikan sesuatu yang tidak menyenangkan (Keraf 2005, 132). Majas termasuk dalam bahasa figuratif yang termasuk dalam kajian gaya bahasa. Keraf memberikan batasan mengenai gaya bahasa sebagai cara mengungkapkan suatu pikiran melalui bahasa secara khas yang memperlihatkan kepribadian penulis (pemakai bahasa) (Keraf 2005, 113). Sementara itu, Tarigan memberikan batasan tentang gaya bahasa sebagai bahasa indah yang digunakan untuk meningkatkan efek dengan jalan memperkenalkan serta membandingkan suatu benda atau hal tertentu dengan sesuatu yang lain yang lebih bersifat umum (Tarigan 1985, 5).

Penelitian tentang gaya bahasa pernah dilakukan oleh Kusumawati (2010) yang menunjukkan bahwa pemakaian gaya bahasa yang digunakan dalam iklan produk kecantikan meliputi personifikasi, retoris, mesodiplosis, anafora, klimak, koreksio, aliterasi, asindenton, epistrofa, antiklimak, repetisi, asonansi, anadiplosis, dan erotesisi. Selanjutnya, Setiawan (2012) meneliti gaya bahasa pada iklan dalam surat kabar Harian Jogja. Hasil penelitian ini menunjukkan bahwa jenis diksi dibedakan menjadi dua, yaitu diksi makna kalimatnya dan luas tidaknya makna. Adapun gaya bahasa yang ditemukan meliputi gaya bahasa klimaks, gaya bahasa antiklimaks, paralelisme, antitesis, dan repetisi.

Kajian mengenai eufemisme dilakukan oleh Bahri (2000) dengan memberikan gambaran efektifitas eufemisme dalam tataran politik dan ruang lingkupnya dalam kehidupan masyarakat. Selain itu, kajian ini ditujukan pula untuk memberikan penjelasan kepada masyarakat agar mampu membedakan opini dan fakta dari bahasa eufimisme yang digunakan elit politik. Nurliasari (2015) meneliti eufemisme pada ujaran politikus Belanda. Tujuan penggunaan eufemisme terbanyak yang ditemukan ditujukan untuk menjaga perasaan orang agar tidak tersinggung. Selain itu, penelitian tersebut menyebut bahwa eufemisme dapat mengalami perubahan makna dari waktu ke waktu. Kata yang dahulu dianggap sebagai eufemisme, kini atau di masa yang akan datang, dapat bermakna biasa apabila terdapat istilah-istilah 
baru yang dianggap lebih baik untuk menggantikan kata tersebut.

Farida, dkk. (2013) meneliti eufemisme pada tajuk rencana Kompas. Tujuan penelitian tersebut adalah untuk mendeskripsikan bentuk, tujuan, dan makna eufemisme yang ada dalam editorial Kompas. Bentuk eufimesme mencakup ekspresi figuratif, pemakaian kata yang terlampau banyak, akronim, dan hiperbola. Adapun penggunaan eufemisme bertujuan untuk salam dan penamaan, penggunaan ekspresi dalam eufemisme, dan situasi ekspresi, sedangkan makna digunakan sebagai penentuan makna denotasi maupun konotasi. Rubby, Tia, dan Dardalia (2008) meneliti eufimisme pada koran Seputar Indonesia. Hasil penelitian menunjukkan bahwa terdapat penggunaan eufemisme pada koran Seputar Indonesia mencakup ekspresi figuratif, flipansion, sircumlution, ringkasan, satu kata untuk menempatkan kata yang lain, bentuk umum ke bentuk khusus, dan hiperbola.

Kajian ini dilatarbelakangi oleh belum adanya pengembangan standar penulisan wacana obituarium di Indonesia. Pengembangan bahan ajar ini penting, terutama untuk kekayaan sumber bacaan teks dalam pelajaran Bahasa Indonesia. Penelitian ini merupakan kajian awal dan diharapkan mampu member kontribusi, terutama untuk penyusunan bahan ajar Bahasa Indonesia berbasis teks yang banyak melibatkan bermacammacam teks. Obituarium, sebagai salah satu jenis teks yang bisa dijadikan sebagai acuan atau dasar dalam pembelajaran bahasa Indonesia, dapat dijadikan sumber untuk mengembangkan bahan ajar berbasis teks.

Kajian eufemisme dalam wacana obituarium merupakan salah satu langkah awal dalam merumuskan pola penulisan dan kekhasan wacana obituarium. Berdasarkan pengamatan awal, gaya bahasa eufemisme banyak ditemukan dalam wacana obituarium. Penelitian awal ini diharapkan dapat mengungkap kekhasan penggunaan gaya bahasa eufemisme dalam wacana obituarium. Lebih dari itu, kajian ini diharapkan dapat menambah khasanah pengetahuan tentang ragam bahasa Indonesia dalam bidang gaya bahasa, khususnya eufemisme. Berdasarkan uraian tersebut terdapat dua rumusan masalah dalam penelitian ini. (1) Bagaimana bentuk gaya bahasa eufemisme yang ditemukan dalam rubrik Obituari Harian Kompas? (2) Apa saja fungsi penggunaan gaya bahasa eufemisme dalam rubrik Obituari harian Kompas?

\section{Metode Penelitian}

Kajian mengenai gaya bahasa dalam wacana obituari surat kabar harian Kompas bersifat deskriptif kualitatif. Data diperoleh dari surat kabar harian Kompas yang terbit sejak bulan Agustus 2015 s.d. April 2016. Sumber data berupa wacana obituari di harian Kompas. Objek penelitian ini adalah gaya bahasa khusus yang muncul dalam wacana berita duka harian kompas. Data diperoleh dengan teknik catat. Kata-kata yang terkumpul diklasifikasikan berdasarkan konteksnya untuk memperoleh deskripsi mengenai bentuk eufemisme yang ditemukan. Setelah itu data dianalisis dengan metode padan dengan teknik padan referensial (Sudaryanto, 1993). Setelah data dianalisis secara kualitatif, langkah selanjutnya adalah menginterpretasikan hasil analisis dengan mengungkapkan kekhasan gaya bahasa khusus yang muncul dalam wacana obituari guna mengidentifikasi fungsi-fungsi penggunaan gaya bahasa eufemisme dalam rubrik Obituari Kompas.

\section{HASIL DAN PEMBahasaN}

Penggunaan gaya bahasa eufemisme dalam rubrik Obituari Kompas terasa lebih santun dan lebih hormat, baik kepada orang yang 
meninggal maupun sanak saudara yang ditinggalkan.

Berdasarkan tataran kata majemuk terdapat 'rumah duka' dan 'tutup usia'. Pada tataran frasa ditemukan 'akhir hayat' dan 'selamat jalan'. Tataran idiom tampak dari kata 'rendah hati'. Sedangkan tata satuan bentuk klausa ditemukan 'perangai nan lembut', 'mengembuskan napas terakhir', 'menghadap Sang Khaliq', dan 'peristirahatan terakhir'.

Eufemisme digunakan untuk mengabarkan bahwa objek yang diberitakan telah tiada. Ungkapan seperti 'meninggal', 'berpulang', 'tutup usia', 'pergi', 'wafat', 'menghembuskan nafas terakhir', dan 'menghadap sang Khaliq' sering digunakan dalam wacana obituarium. Kata 'meninggal' digunakan dalam 24 dari 28 teks obituari. Kata 'meninggal' disematkan pada semua objek baik laki-laki dan perempuan, semua profesi, dan semua usia. Kata 'meninggal' digantikan dengan kata 'berpulang' pada teks obituari Guru Kader NU Telah Berpulang, Pak Raden-Memori Abadi Generasi 'Ini Budi', dan Edhi Sunarso Berpulang Karya-Karyanya Abadi,

Kata ini disematkan pada tokoh organisasi masyarakat yaitu Slamet seorang yang dikenal sebagai guru kader NU dan Teungku Imam Syuja' yang dikenal sebagai tokoh Muhammadiyah. Kata 'berpulang' juga disematkan pada seorang seniman yakni Suyadi dikenal dengan nama pak Raden. Eufemisme berpulang juga disematkan pada seorang seniman nasional Edhi Sunarso. Kata 'wafat' dan 'tutup usia' disematkan untuk memberitakan seorang Prof. Zuhal yang dikenal sebagai ilmuwan dalam inovasi pendidikan.

Umumnya satu teks obituari hanya menggunakan satu kata yang digunakan untuk mengabarkan bahwa objek telah tiada, tetapi tidak jarang menggunakan lebih dari satu kata. Kata 'meninggal', 'berpulang', dan 'wafat' digunakan bersama dalam satu teks obituarium, sebagaimana dalam teks obituari yang berjudul Mantan Dirut Pertamina Berpulang. Berdasarkan hasil analisis tidak ada syarat khusus dalam penggunaan katakata yang dideskripsikan di atas.

Eufemisme yang digunakan untuk mendeskripsikan tubuh yang telah meninggal pada teks obituari yaitu 'mendiang', 'almarhum', 'sosok', 'beliau', dan 'jenazah'. Kata 'jenazah' digunakan dalam 13 teks, 'almarhum' digunakan di 14 teks, 'sosok' 4 teks, 'beliau' 6 teks obituari dan 'mendiang' satu teks obituari. Namun tidak jarang digunakan dua penyebutan untuk orang yang mati. Misalnya dalam judul Guru Kader NU itu Telah Berpulang disebutkan kata 'almarhum' dan 'jenazah'. Kata 'mendiang' hanya ditemukan dalam satu teks dalam judul Mgr Sol Tutup Usia Ambonia Berduka.

Pemilihan kata yang digunakan tidak terdapat syarat khusus yang mengikat, baik dilihat dari profesi, usia, maupun gender. Berikut contoh penggunaan gaya bahasa eufemisme kata 'meninggal' dalam wacana obituari.

Vincentius Bata (VB) da Costa, yang pernah menjadi anggota DPR dari fraksi PDI, yang menjadi PDI Perjuangan (PDI-P), meninggal dalam usia 89 tahun di kediamannya, Jalan Wijaya Kusuma, Cilandak, Jakarta, Kamis lalu. (Kompas, 14 Februari 2016, 'Sulit Temukan Sosok Seperti Da Costa di DPR').

Gaya bahasa eufemisme 'meninggal' pada data di atas berfungsi untuk mengabarkan kepergian VB Dacosta untuk selama-lamanya. Gaya bahasa eufemisme meninggal lebih santun dari kata mati dan tewas. Kata meninggal dipilih karena VB Dacosta memiliki kedudukan yang tinggi di masyarakat yaitu pernah menjadi anggota DPR.

Berikut contoh penggunaan gaya bahasa eufemisme kata ‘jenazah' dalam wacana obituari. 
"Ireng tidak akan pernah pergi Setiap ada pertunjukan music jazz di Indonesia, di sana ada Ireng Maulana karena dialah penjaga music jazz Indonesia ," ujar tokoh perfilman Eros Djarot, kemarin, di ruang KunziteLazulitte, Rumah Duka Dharmais, Jakarta, Tempat jenazah Ireng disemayamkan (Kompas, 7 Maret 2016, 'Karya Ireng Maulana Tak Pernah Pupus').

Gaya bahasa eufemisme kata 'jenazah' yang digunakan dalam wacana obituari lebih santun dari kata mayat. Hal ini bertujuan untuk menghormati objek yang diberitakan dan keluarga yang ditinggalkan. Penghormatan ini diberikan atas karya-karya objek yang diberitakan.

Berikut contoh penggunaan gaya bahasa eufemisme kata 'almarhum' dalam wacana obituari.

Almarhum langsung dimakamkan di tempat Pemakaman Umum Tegalboto, Jember, Jawa Timur bersebelahan dengan istrinya Siti Faridah yang meninggal enam tahun lalu.

Kata 'almarhum' lebih sering digunakan dalam penyebutan objek yang diberitakan dalam wacana obituari. Hal tersebut muncul karena keinginan penulis wacana obituari untuk memperoleh kata yang lebih santun sehingga tidak menyinggung perasaan pihak-pihak tertentu, dalam hal ini keluarga yang ditinggalkan dan kerabat yang berduka.

Bentuk gaya bahasa eufemisme wacana obituari ditemukan kata 'berpulang', 'meninggal', 'jenazah', 'disemayamkan', 'rumah duka', 'dimakamkan', 'almarhum', 'dukacita', 'peninggalan', 'dikebumikan', 'pergi', 'jasa', 'wafat', 'kepergian', 'akhir hayat', 'rendah hati', 'perangai nan lembu't, 'kehilangan', 'pemakaman', 'selamat jalan', 'mantan', 'sosok', 'mengembuskan napas terakhir', 'bermukim', 'ujar', 'telah tiada', 'dekade', 'meninggal dunia', 'beliau', 'tutur', 'mengenang', 'tutup usia', 'usia', 'berduka', 'duka mendalam', 'menuturkan', 'dirujuk', 'mendiang', 'ditasbihkan', 'makam', 'peristirahatan terakhir', 'menghadap Sang Khaliq', dan 'wasiatnya'.

Berdasarkan tata satuan bentuk bahasa, gaya bahasa eufemisme yang muncul dalam rubrik harian kompas di atas dapat dirinci sebagai berikut: 1) kata 2) kata majemuk 3) frase, 4) klausa dan 5) idiom. Gaya bahasa dalam wacana obituari harian Kompas yang termasuk dalam tataran kata ialah 'berpulang', 'meninggal', 'jenazah', 'disemayamkan', 'dimakamkan', 'almarhum', 'dukacita', 'peninggalan', 'dikebumikan', 'pergi', 'jasa', 'wafat', 'kepergian', 'kehilangan', 'pemakaman', 'mantan', 'sosok', 'bermukim', 'ujar', 'dekade', 'beliau', 'tutur', 'mengenang', 'usia', 'berduka', 'menuturkan', 'dirujuk', 'mendiang', 'ditasbihkan', 'makam' dan 'wasiatnya'.

Dengan didasarkan pada kajian bentuk, fungsi penggunaan eufemisme dalam wacana obituari harian Kompas yakni memilih kata yang lebih santun, tidak menyinggung keluarga serta pihak-pihak tertentu, dan menghormati objek yang diberitakan atas jasa ataupun karya yang dihasilkan oleh objek yang diberitakan. Fungsi penggunaan eufemisme ini mengacu data yang ditemukan pada penggunaan eufemisme dalam rubrik obituari.

Fungsi pertama adalah fungsi kesantunan. Fungsi ini dimanfaatkan oleh penulis rubrik obituari untuk memberi kesan santun dan layak untuk dibaca. Berikut contoh penerapan fungsi kesantunan.

Ali Wardhana meninggal pada usia 87 tahun, Senin (14/9) petang, di Rumah Sakit Mediatra, Kuningan, Jakarta Selatan. (Kompas, 16 September 2015, 'Ali Wardhana')

'Meninggal' merupakan kata yang sering dimunculkan dalam rubrik obituari. Kata 'meninggal' menggambarkan kondisi seseorang yang sudah tidak bernyawa atau seseorang yang sudah meninggalkan dunia. Pemilihan kata 'meninggal' 
dirasa lebih santun dibandingkan dengan kata 'mati'.

Fungsi selanjutnya yaitu fungsi tidak menyinggung keluarga. Pilihan kata yang dipilih oleh penulis obituari telah dipikirkan dengan baik untuk tidak menyinggung atau menyakiti perasaan keluarga yang ditinggalkan oleh objek yang diberitakan meninggal. Oleh karena itu, tulisan tidak akan menimbulkan luka yang lebih mendalam dan tidak menyakiti perasaan keluarga yang ditinggalkan.

Jenazah Mantan Menteri Keuangan (1968-1983) serta Menteri Koordinator Ekonomi, Industri, dan Pengawasan Pembangunan (19831988) pada era pemerintahan Presiden Soeharto, Prof Dr Ali Wardhana, dimakamkan secara militer di Tempat Pemakaman Umum Tahah Kusir, Jakarta, Selasa (15/9) (16 September 2015, Ali Wardana)

Selain untuk memilih kata yang santun dan fungsi untuk tidak menyinggung keluarga yang ditinggalkan, ada pula fungsi untuk menghormati objek yang diberitakan. Kata-kata hormat yang digunakan biasanya digunakan untuk menghormati objek yang meninggal karena jasa-jasa yang dibuat semasa hidupnya. Contoh penerapannya terlihat dari kata berikut.

Istri almarhum, Arni Sultan (53), mengatakan, Fahmy sempat dirawat selama tiga hari di rumah sakit sebelum mengembuskan napas terakhir.

Kata 'almarhum' lebih sering digunakan dari pada kata 'ia', 'dia', dan 'jenazah'. Kata 'almarhum' dirasa dapat menghormati juga meninggikan derajat orang yang sudah meninggal. Penghormatan diberikan karena jasa dan pengabdian yang diberikan oleh objek obituari.

\section{KESIMPULAN}

Berdasarkan hasil dan pembahasan dari kajian ini, dapat ditarik kesimpulan bahwa salah satu kekhasan penulisan teks obituari terletak pada penggunaan eufemisme. Bentuk eufemisme pada wacana obituari berupa kata, kata majemuk, idiom, klausa dan kalimat. Penggunaan eufemisme pada teks obituari memiliki fungsi. Penggunaan eufemisme dalam wacana obituari harian Kompas berfungsi memilih kata yang lebih santun, tidak menyinggung keluarga serta pihak-pihak tertentu, lebih prestise dan menghormati objek yang diberitakan atas jasa ataupun karya yang dihasilkan oleh objek yang diberitakan.

\section{Daftar Pustaka}

Agni, Binar. 2009. Sastra Indonesia Lengkap: Pantun Puisi Majas Peribahasa Kata Mutiara. Jakarta: Hi-Fest Publising.

Bahri, Syamsul. 2000. Eufemisme dalam Wacana Politik. Medan: Fakultas Bahasa dan Seni, Universitas Negeri Medan.

Farida, Nur, Auzar, dan Husnah Faizah. 2013. "Penggunaan Eufemisme dalam Tajuk Rencana Koran Kompas". Artikel Ilmiah. Riau: Pendidikan Bahasa dan Sastra Indonesia, Universitas Riau.

Keraf, Gorys. 2005. Diksi dan Gaya Bahasa. Jakarta: Gramedia Pustaka Utama.

Kusumawati. 2010. "Analisis Pemakaian Gaya Bahasa pada Iklan Produk Kecantikan Perawatan Kulit Wajah di Televisi". Jurnal Penelitian. Surakarta: Universitas Sebelas Maret.

Lakoff, George dan Mark Johnsen. 2003. Metaphors We Live by. London: The University of Chicago Press.

Nurliasari, Dian. 2015. "Penggunaan Eufemisme dalam Ujaran-ujaran langsung Politikus Belanda pada Artikel Politik Majalah Vrij Nederland" (Skripsi) Jakarta: Universitas Indonesia.

Rubby, Tia dan Dardalia. 2008. "Eufemisme pada Harian Seputar Indonesia". Jurnal Ilmu Bahasa dan Sastra (4) 1 
Setiawan, Henryanoor. 2012. "Gaya Bahasa Dilihat Berdasarkan Diksi dan Struktur dalam Iklan Display Wacana Iklan Rawit pada Surat Kabar Harian Jogja". Skripsi. Yogjakarta: Universitas Negeri Yogyakarta.

Sudaryanto. 1993. Metode dan Teknik Analisis Bahasa: Pengantar
Penelitian Wahana Kebudayaan secara Linguis. Yogyakarta: Duta Wacana University Press.

Tarigan, Henry Guntur. 1985. Pengajaran Gaya Bahasa. Bandung: Angkasa. 
